\title{
Validity and reliability of the coronavirus anxiety scale: Turkish adaptation for nurses
}

\section{Koronavirüs anksiyete ölçeğinin geçerlik ve güvenirliği: hemşireler için}

Türkçeye uyarlanması

\author{
Sadık Hançerlioğlu ${ }^{1}$ Filiz Özel ${ }^{2}$ Gülbin Konakçı ${ }^{3}$ (D) \\ ${ }^{1}$ Department of Internal Medicine Nursing, Ege University Faculty of Nursing, Izmir, Turkey \\ ${ }^{2}$ Department of Internal Medicine Nursing, Kastamonu University Faculty of Health Science, Kastamonu, Turkey \\ ${ }^{3}$ Department of Internal Medicine Nursing, University of Democracy, Faculty of Health Sciences, Izmir, Turkey
}

\section{ABSTRACT}

Aim: The purpose of our study was to assess the validity and reliability of the Coronavirus Anxiety Scale for Turkish nurses.

Materials and Methods: Content validity index (CVI), principles component analysis, Cronbach's alpha, parallel form, and test-retest methods were used.

Results: CVI was 0.98 (0.96-0.99). A one-factor solution was identified and the factor loading of items in scale was between 0.636 and 0.893 . The Cronbach's alpha value was found 0.84 . Intraclass Correlation Coefficient was between 0.84 to 0.92 .

Conclusion: Turkish version of the Coronavirus Anxiety Scale for nurses was found to be valid and reliable to measure the anxiety of nurses towards COVID-19.

Keywords: COVID-19, anxiety, nursing, validity, reliability.

\section{ÖZ}

Amaç: Çalışmamızın amacı, Koronavirüs anksiyete ölçeğinin hemşireler için Türkçe versiyonunun geçerlilik ve güvenilirliğini değerlendirmektir.

Gereç ve Yöntem: İçerik geçerlilik indeksi (CVI), principles component analizi, Cronbach's alpha, paralel form ve test-tekrar test yöntemleri kullanılmıştır.

Bulgular: CVI 0,98 (0,96-0,99) olarak bulunmuştur. Tek faktörlü çözüm belirlenmiş ve ölçekteki maddelerin faktör yükleri 0.636 ile 0.893 arasındadır. Cronbach alfa değeri 0,84 olarak bulunmuştur. Sınıf içi korelasyon Katsayısı 0,84 ile 0,92 arasında bulunmuştur.

Sonuç: Hemşireler için koronavirüs anksiyete ölçeğinin Türkçe versiyonu, hemşirelerin COVID-19'a yönelik kaygılarını ölçmek için geçerli ve güvenilir bulunmuştur.

Anahtar Sözcükler: Covid-19, anksiyete, hemşirelik, geçerlik, güvenirlik.

\section{INTRODUCTION}

In late December 2019, in Wuhan Province in China a group of patients developed respiratory tract symptoms such as fever, cough and shortness of breath. Upon examining those patients, the new Coronavirus (SARS-CoV-2) was identified on January 13, 2020. First, the virus was detected in People who had recently visited the seafood and animal market in this region, after that it has spread from person to person and spread to other cities, mainly Wuhan, and other provinces of the Republic of China and all over the world.

\footnotetext{
Corresponding author: Sadik Hançerlioğlu

Department of Internal Medicine Nursing, Ege University

Faculty of Nursing, Izmir, Turkey

E-mail: s_hancerlioglu@hotmail.com

Application date: 19.11.2020

Accepted: 08.12.2020
} 
The epidemic was declared as a pandemic, on March 11, 2020, by the World Health Organization (1, 2). As of November 2020, more than 57 million confirmed cases and 1.300 .000 deaths have been reported in the world (3). Fever, cough, and shortness of breath have been reported among the main symptoms of COVID19. In addition to these symptoms, there are cases who presented with sore throat, weakness, malaise, joint-muscle pain in other viral infections (4).

Because of the high infection and mortality rates, people and governments worldwide began to worry about the virus (5). Wu et al. (2005) reported that an incidence of depression, anxiety and post-traumatic stress disorder symptoms was between $10 \%$ and $18 \%$ during and after the Severe Acute Respiratory Syndrome (SARS) epidemic (6). Cao et al. (2020) determined that about $24.9 \%$ of college students have experienced anxiety due to the COVID-19 outbreak (7). Liu et al. (2020) determined that the prevalence rate of traumatic stress was at an alarming $73.4 \%$, depression was at $50.7 \%$, generalized anxiety was at $44.7 \%$, and insomnia was at $36.1 \%$ among health care professionals (8).

Nurses, within their professional scope of duty, have to be in contact with infected or possibly infected individuals within various healthcare settings. Therefore, they are anxious. Yet, in order to protect the overall well-being of nurses, and to provide more effective care, it is very important to evaluate the anxiety experienced by nurses due to COVID-19 (9). However, there is no valid and reliable tool to evaluate their levels of anxiety as associated with working with COVID-19 patients. Sherman A. Lee (2020) developed the Coronavirus Anxiety Scale for the general population (10). In this study, we aimed to culturally adapt, evaluate the validity and reliability of The Coronavirus Anxiety Scale (CAS) for nurses in Turkey.

\section{MATERIALS AND METHODS}

\section{Study Design}

The study used a descriptive design and was conducted between April - June 2020. The participants were 165 nurses who were working in a university hospital in Turkey. Inclusion criteria were as follows: nurses who could communicate in Turkish, working for more than six months as a nurse, and accepted to participate in the study. The convenience sampling design was used for the study.

\section{Data Collection}

A nurse identification form, CAS and Generalized Anxiety Disorder Test-7 (GAD-7) were used for data collection of the study. Data were collected via an online survey. A mail or message was sent to the nurses that included informed consent and a link for the survey. Thus, social contact and virus transmission risk were reduced. Another advantage of this method is that nurses can complete the form at their own convenience.

\section{Nurse Identification Form}

This form was developed by the research team including age, gender, marital status, education levels, and working years in nursing.

\section{The Generalized Anxiety Disorder-7 (GAD-7)}

The Generalized Anxiety Disorder-7 (GAD-7) was developed by Spitzer et al. (11). GAD-7 evaluates generalized anxiety disorder according to DSM-IV-TR criteria. It contains 7 items that assess the experiences during the last 2 weeks. It is Likert type scale which is the quadruple form. In the form, "0" means none, "1" means many days, "2" means more than half of the days, "3" means almost every day. The total score of 5 obtained in the scale is cut-off points for mild, 10, moderate, and 15, severe anxiety (12). The validity and reliability study of the scale in Turkish was carried out by Konkan et al. (13). Turkish version of the scale was found to have high validity and reliability. The most acceptable cutoff point of the Turkish version was found to be 8 (13).

\section{The Coronavirus Anxiety Scale}

The coronavirus anxiety scale (CAS) was developed by Sherman A. Lee (10). The scale is a self-report mental health screener measures dysfunctional anxiety associated with the coronavirus crisis. The scale consist of 5 item and each item is rated from 0 to 4 . If the answer is "0", it means "not at all", and if "4" it means "nearly every day" and answers need to be given according to the experiences over the past two weeks. This scaling format is prepared according to be consistent with DSM-5's cross-cutting symptom measure. High scores on a particular item or a higher total scale score than 9 may indicate problematic symptoms for the individual that might warrant further assessment and/or treatment. 
Validity of Coronavirus Anxiety Scale

\section{Language Validity}

MAPI Research Institute guidelines were followed for the language validation of the scale (Table-1) (14).

\section{Content Validity}

The Turkish version of the form was evaluated by the academicians and clinicians working in the faculty of nursing of a university and university hospital in terms of content validity. The experts were asked to evaluate the suitability, comprehensibility, and simplicity of each item in the scale.

\section{Construct Validity}

To determine construct validity, Principal component analysis method was used. Bartlett's and Kaiser-Meyer-Olkin (KMO) test were used to determine suitability of the data for factor analysis.

\section{Reliability of Coronavirus Anxiety Scale}

In this study, split half-test (split-half) (calculated as odd-numbered and even-numbered questions separately) and Cronbach's Alpha methods were used to calculate internal consistency. The relationship between the scale scores obtained from the test and retest was evaluated by using the intraclass correlation coefficient (ICC) to evaluate the test-retest reliability. It is reported that the number of individuals to be retested should be at least 30 in testing invariance against time (15). For retest analysis, nurses choose a nickname for themselves, and the forms were reapplied to the 30 nurses after two weeks. For psychometric reliability, there are three primary classifications; Parallel forms reliability is one of this classification along with test-retest reliability and internal consistency reliability (16). GAD-7 was used for parallel form reliability.

\section{Statistical analyses}

A total of 170 nurses were surveyed but only 165 were included in the final analysis due to missing values in some questions. IBM SPSS 22.0 package program was used for Cronbach's alpha reliability coefficient, factor analysis, correlations, Bartlett's test and KMO Test.

\section{Ethics}

In order to evaluate the validity and reliability of scale, necessary permissions were obtained from copyright owner (Sherman A. Lee) and the Ege University Ethics Committee of Medical Research (Decision no: 20-6T/7). All directives of the Helsinki Declaration have been followed and informed consent was obtained from all participants.

\section{RESULTS}

Of the participants, $70.7 \%$ were female, $63.5 \%$ were single and $67.1 \%$ had bachelor's degree or higher education. The mean age of the participants was $29.77( \pm 7.10)$ years and mean working years was $7.90( \pm 7.76)$. After translation of the scale, CVI was used to determine content validity. The CVI of the scale was 0.98 (0.960.99). The KMO value (0.86) and Bartlett sphericity test $\left(X^{2}: 1042.079\right.$, df: $\left.18, p<0.001\right)$ showed that the data is suit for the factor analysis. The performed factor analysis indicated one factor with eigen value over 1.0. One-factor structure explained $61.24 \%$ of the total variance. Factor loadings ranged between 0.636 and 0.893 (Table-2).

The Cronbach's Alpha value of the CAS for nurses was 0.84, the Guttman Split-Half coefficient was 0.71 , and the Spearman-Brown coefficient was 0.78 . The Cronbach's Alpha value of the first half was 0.82 and the second half was 0.64 , the correlation between the two halves was 0.63 (Table-3). ICC results of the first and second application of the CAS for nurses was 0.86 (Table-4). CAS for Nurses shows a statistically significant and positive correlation with the GAD7 scale (Table-5).

Table-1. Language validity stages of coronavirus anxiety scale.

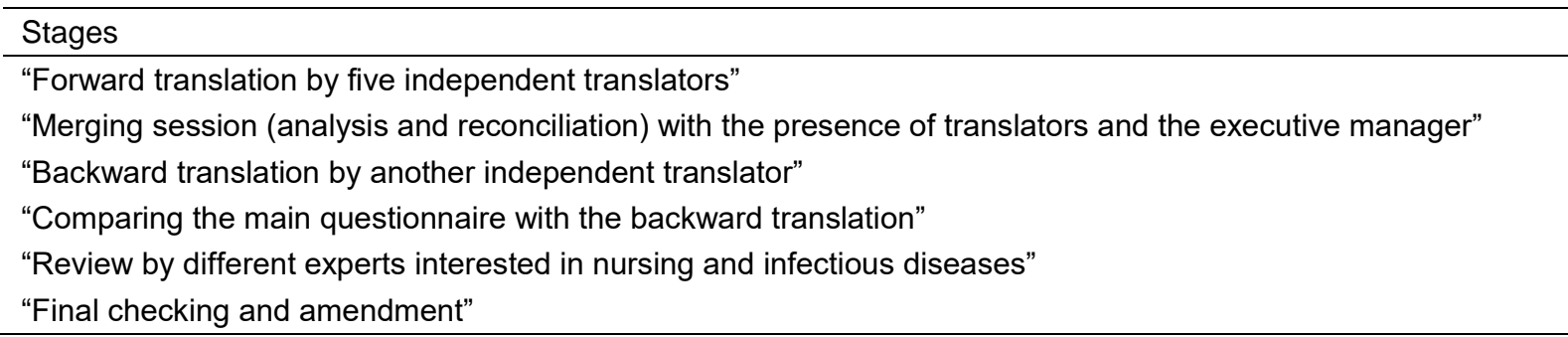


Table-2. Factor loadings of coronavirus anxiety scale for nurses.

\begin{tabular}{lc}
\hline Items & Factor 1 \\
\hline 1. I felt dizzy, lightheaded, or faint, when I read or listened to news about the & 0.893 \\
2. I had trouble falling or staying asleep because I was thinking about the coronavirus. & 0.818 \\
3. I felt paralyzed or frozen when I thought about or was exposed to information about & 0.798 \\
the coronavirus. & 0.636 \\
4. I lost interest in eating when I thought about or was exposed to information about the \\
$\begin{array}{l}\text { coronavirus. } \\
\text { 5. I felt nauseous or had stomach problems when I thought about or was exposed to }\end{array}$
\end{tabular}

Extraction Method: Principal Component Analysis.

$\mathrm{N}: 165$

Table-3. Reliability analysis of the coronavirus anxiety scale for nurses.

\begin{tabular}{ll}
\hline Reliability Analysis & Value \\
\hline Cronbach's Alpha of the scale & 0.84 \\
Guttman Split-Half & 0.71 \\
Spearman-Brown & 0.78 \\
3-item First Half Cronbach's Alpha Value & 0.82 \\
2-item Second Half Cronbach's Alpha Value & 0.64 \\
Correlation between two halves & 0.63 \\
\hline
\end{tabular}

Table-4. Coronavirus anxiety scale for nurses test-retest reliability.

\begin{tabular}{lc}
\hline Scale & ICC (Min. - Max.) \\
\hline CAS for Nurses & $0.86(0.84-0.92)$ \\
\hline
\end{tabular}

Table-5. Findings on Parallel Form Reliability

\begin{tabular}{lr}
\hline Scales & CAS for Nurse \\
\hline The Generalized Anxiety Disorder-7 Scale & $r=0.523$ \\
& $\mathrm{p}=0.000$ \\
${ }^{* *}$ Correlation is significant at the 0.01 level & $\mathrm{n}=165$
\end{tabular}

\section{DISCUSSION}

In the current study, translation and backtranslation studies on the language validity of the CAS for nurses were conducted according to the MAPI Research Institute guidelines (14). CVI was used to evaluate the scope validity. A CVI score above 0.80 indicates that the validity of the scope is achieved (17). In this study, CVI was determined as $0.98(0.96-0.99)$. This value indicates that the content validity is high. In order to evaluate factor structure, Principal Component Analysis (PCA) was performed. In order to perform Principal Component Analysis within the context of construct validity, KMO sample adequacy analysis and Bartlett's test should be performed and a value of 0.60 and above should be obtained (18). For this reason, at this stage, $\mathrm{KMO}$ sample adequacy analysis (KMO: 0.86 ) and Bartlett's sphericity analysis were conducted to evaluate whether the sample was suitable for factor analysis and test $\left(X^{2}: 1042.079\right.$, df: 18, p $<0.001)$ was found significant. As a result of the analysis, the structure consisting of one factor whose eigen value is above 1.0 explains $61.24 \%$ of the total variance. In the literature, it is stated that $50 \%$ and above variance rates are accepted as valid (19). Our results obtained from the study is in line with the literature with this context. The 
item factor loadings ranged between 0.63 and 0.89 in PCA. It was reported in the literature that the item factor loadings $<0.30$ should be excluded from the scale (19). Thus, the original structure and items of the scale was preserved in Turkish version also. The factor loadings of items of the scale in development study were reported between 0.81 and 0.84 (10). These findings of our study are similar to those reported in the literature.

If the alpha coefficient is less than 0.40 , the measurement tool is not reliable, low reliability between $0.40-0.59$, highly reliable between 0.60 0.79 , and highly reliable between 0.80-1.00 (20). We found that the Cronbach's alpha value of the CAS for nurses was 0.84 in the current study. The Cronbach's alpha of the scale was reported to 0.93 in a development study (10). The Guttman split-half reliability coefficient of the scale was 0.71 ; The Spearman-Brown coefficient was 0.78 ; The Cronbach's Alpha value of the first half was 0.82 ; and the second half was 0.64 ; the correlation between the two halves was 0.63 . The reliability coefficient that can be considered sufficient in a measurement tool should be as close to 1 as possible. If the alpha coefficient is less than 0.40 , the measuring tool is not reliable, it is considered to be low reliability between 0.40 and 0.59 , highly reliable between 0.60 and 0.79 , and highly reliable between 0.80 and 1.00 (20). It can be said that the reliability of the scale is highly reliable according to the literature information. Higher correlations between repeated measurements shows higher stability of the scale (21). If the ICC values are less than 0.5, it indicates poor reliability. If values are between 0.5 and 0.75 , it indicates moderate reliability. If values are between 0.75 and 0.9 , it indicates good reliability and values greater than 0.90 indicate excellent reliability (22). In the current study, the values from 0.84 to 0.92 indicate that the excellent degree of reliability. Valid and reliable parallel forms were used to determine parallel form reliability. We used The Generalized Anxiety Disorder-7 Scale as parallel form. In the current study, we found that there were positive and statistically significant relationships between The Generalized Anxiety Disorder-7 Scale and Coronavirus Anxiety Scale. These findings support the reliability of Turkish version of the scale.

\section{CONCLUSION}

According to the results of all statistical analyzes conducted to evaluate the validity and reliability of the Coronavirus Anxiety Scale for nurses, we concluded that the Coronavirus Anxiety Scale for nurses was a valid and reliable tool to measure anxiety of nurses related to coronavirus.

This tool can be used in clinical studies to measure anxiety of nurses related to coronavirus or comparison of nurses' anxiety related to coronavirus with other features like working conditions.

We recommend evaluating the validity and reliability of the scale for different groups.

\section{Acknowledgments}

We thank the nurses for their participation.

\section{Funding}

This research did not receive any funding from anywhere.

Conflict of Interest: The authors declared no conflict of interest.

\section{References}

1. World Health Organization (2020a). Novel Coronavirus (2019nCoV) situation reports [online]. https://www.who.int/emergencies/diseases/novel-coronavirus 2019/situation reports [Access date: June 2020].

2. World Health Organization (2020b). Coronavirus Disease (COVID-19) events as they happen [online]. https:// www.who.int/emergencies/diseases/novel-coronavirus-2019/ events-as-they-happen [Access date: June 2020].

3. COVID-19 Map - Johns Hopkins Coronavirus Resource Center, https://coronavirus.jhu.edu/map.html [Access date: June 2020].

4. Cui J, Li F and Shi ZL. Origin and evolution of pathogenic coronaviruses. Nature Reviews Microbiology 2019; 17 (3): 181-192.

5. Lin CY. Social reaction toward the 2019 novel coronavirus (COVID-19). Social Health and Behavior 2020; 3 (1): 1. 
6. Wu KK, Chan SK, Ma TM. Posttraumatic stress, anxiety, and depression in survivors of severe acute respiratory syndrome (SARS). Journal of Traumatic Stress: Official Publication of The International Society for Traumatic Stress Studies 2005; 18 (1): 39-42.

7. Cao W, Fang Z, Hou G et al. The psychological impact of the COVID-19 epidemic on college students in China. Psychiatry research 2020; 112934.

8. Liu S, Yang L, Zhang C et al. Online mental health services in China during the COVID-19 outbreak. The Lancet Psychiatry 2020;7(4): 17-18.

9. Jennings BM, Yeager KA. From Fear to Fortitude: Using the Power Within the Nursing Profession to Fight COVID-19. Nurs Outlook. 2020; 68 (4): 391-32.

10. Lee SA Coronavirus Anxiety Scale: A brief mental health screener for COVID-19 related anxiety. Death studies 2020; 44 (7): 393-401.

11. Spitzer RL, Kroenke K, Williams JB et al. A brief measure for assessing generalized anxiety disorder: the GAD-7. Archives of internal medicine 2006; 166 (10): 1092-7.

12. Kroenke K, Spitzer RL, Williams JB, et al. Anxiety disorders in primary care: prevalence, impairment, comorbidity, and detection. Annals of internal medicine 2007;146 (5): 317-325.

13. Konkan R, Senormanci O, Guclu O, et al. Validity and Reliability Study for the Turkish Adaptation of the Generalized Anxiety Disorder-7 (GAD-7) Scale. Archives of Neuropsychiatry 2013; 50: 53-8.

14. MAPI Research Institute, Linguistic validation. Available at https://mapi-trust.org/pro_newsletter/mapiwebinar-series/ Accessed June 2020.

15. Bujang, MA, Baharum N A simplified guide to determination of sample size requirements for estimating the value of intraclass correlation coefficient: a review. Archives of Orofacial Science 2017; 12 (1).

16. Salkind NJ (Ed.) Encyclopedia of research design (Vol. 1). Sage. 2010

17. Yusoff MSB. ABC of content validation and content validity index calculation. RESOURCE 2019;11 (2).

18. Chan LL, Idris N. Validity and reliability of the instrument using exploratory factor analysis and Cronbach's alpha. International Journal of Academic Research in Business and Social Sciences 2017; 7 (10): 400-0.

19. Hyuncheol K. A Guide on the Use of Factor Analysis in the Assessment of Construct Validity. Journal of Korean Academy of Nursing 2013; 43 (5).

20. Tavakol M, Dennick R. Making sense of Cronbach's alpha. International journal of medical education 2011;2: 53.

21. Vaz S, Falkmer T, Passmore AE et al. (The case for using the repeatability coefficient when calculating testretest reliability. PloS one 2013; 8 (9): 73990.

22. Koo TK, Li MY. A guideline of selecting and reporting intraclass correlation coefficients for reliability research. Journal of chiropractic medicine 2016; 15 (2): 155-163. 